HORTSCIENCE 25(3):368-369. 1990.

\title{
'Val-Tex 54' and 'Val-Tex 55': Spring Lettuce Cultivars for Southern Texas
}

\section{P.W. Leeper ${ }^{1}$ and B. Scully ${ }^{2}$ \\ Texas Agricultural Experiment Station, Texas A\&M University, Weslaco, TX 78596-8399}

Additional index words. Lactuca sativa, tipburn resistance, downy mildew, pedigree breeding

The spring lettuce crop in southern Texas is planted from late November to mid-December and harvested in March and April. This production period is dominated by 'Golden State D' and 'Valverde'. 'Val-Tex 54' and 'Val-Tex 5.5' were developed and selected for the semi-desert conditions that exist during this production period. Adaptation requires tolerance to occasional frosts in the seedling stage, heat tolerance at heading, slow bolting, and tipburn resistance. Resistance to downy mildew (Bremia lactucae Regl.), particularly races 5 and 6 , is essential (Sleeth and Leeper, 1966; Jones and Leeper, 1971). The name Val-Tex indicates the Rio Grande Valley of Texas; 54 and 5.5 were incidental plot numbers.

\section{Origin}

'Val-Tex 54' and 'Val-Tex 55' were developed by a modified pedigree method that included four hybridizations and repeated single-plant selection (Fig. 1). The original male parent was $\mathrm{W} 210$, an $\mathrm{F}_{4}$ selection derived from a cross between DMR-D, a downy mildew-resistant genotype, and 'Great Lakes 66' (T.W. Whitaker, personal communication). The original female parent was 'Primaverde'. Progenies from this cross were selfed to $\mathrm{F}_{6}$, when W618-3 was selected. In

Received for publication 21 Feb. 1989. TAES Technical Article no. 24457. This research was supported in part by the South Texas Lettuce Committee. The cost of publishing this paper was defrayed in part by the payment of page charges. Under postal regulations, this paper therefore must be hereby marked advertisement solely to indicate this fact.

${ }^{1}$ Professor Emeritus.

${ }^{2}$ Assistant Professor. this generation, W618-3 was crossed as the male parent with breeding line W644, a fourth generation selection from PI 274-900. From this cross, W775-1 was selected in the $F_{2}$ and used as the female parent in a cross with 'Calmar' (Welch et al., 1965). Single-plant selection was practiced until $\mathrm{F}$,, when W77197-1 and W77-197-2 were identified as suitable breeding lines for the late winter/ early spring harvest. Within each of these lines, single-plant selection was practiced for two generations and 54MCh and 55MCh were selected from W77-197-1 and W77-197-2, respectively. These lines were evaluated for 2 seasons and named 'Val-Tex 54' and 'ValTex 55', respectively, in the $\mathrm{F}_{13}$ (Fig. 1).

\section{Description}

'Val-Tex 54' and 'Val-Tex 55' are "Type 2" crisphead lettuces, as defined by the Great Lakes cultivars (Ryder, 1987; Bohn and Whitaker, 1951). Outer leaves are bright medium green with serrated margins. Internal leaves are golden yellow. We judge leaf thickness, texture, crispness, and flavor characteristics as similar to 'Great Lakes 659'. Leaf midribs are flatter and straighter than the Great Lakes type but similar to the Vanguard type (Type 3) (Ryder, 1987). 'Val-Tex 54' and 'Val-Tex 55' have deeper and rounder heads than most of the Great Lakes strains. 
Table 1. Comparison of economic traits of 'Val-Tex 54' and 'Val-Tex 55' with the standard spring cultivars grown in the lower Rio Grande Valley of Texas.'

\begin{tabular}{lcccr}
\hline \hline \multicolumn{1}{c}{ Cultivar } & $\begin{array}{c}\text { Fresh yield } \\
\left(\mathrm{mg}^{\circ} \mathrm{ha}^{-1}\right)\end{array}$ & $\begin{array}{c}\text { Marketable heads at } \\
\text { first harvest } \\
(\%)\end{array}$ & $\begin{array}{c}\text { Head wt } \\
(\mathrm{kg} / \text { head })\end{array}$ & Tipburn (\%) \\
\hline Val-Tex 54 & $54.7 \pm 7.2$ & $50.3 \pm 24.0$ & $1.2 \pm 0.5$ & $25.0 \pm 21.2$ \\
Val-Tex 55 & $53.9 \pm 11.3$ & $53.7 \pm 6.7$ & $1.2 \pm 0.1$ & $30.0 \pm 42.4$ \\
Golden State D & $52.5 \pm 10.3$ & $50.0 \pm 30.0$ & $1.2 \pm 0.5$ & $30.0 \pm 0.0$ \\
Valverde & $46.0 \pm 11.6$ & & $1.0 \pm 0.0$ & $5.0 \pm 7.1$ \\
\hline
\end{tabular}

${ }^{\mathrm{z}}$ Based on two sites over 2 years, with two replications per site.

Both cultivars carry resistance to races 5 and 6 of downy mildew (Bremia lactucae Regl.) and have greater resistance to predamage and premature bolting than 'Golden State D' or 'Valverde'. 'Val-Tex 54' and 'Val-Tex 55' averaged greater yields and required fewer harvests than the standard cultivars in trials over 2 seasons in Weslaco, Texas (Table 1). Head mass in both cultivars was equivalent to the standard cultivars, while tipburn was more severe than in 'Valverde'.

\section{Availability}

Foundation seed was distributed to 10 seed companies in 1984 and is currently available from Shamrock Seed Co., Salinas, Calif., and Peta Seed Co., Woodland, Calif. Breeders seed has also been deposited in the USDA lettuce cultivar collection held in Salinas, Calif.

\section{Literature Cited}

Bohn, G.W. and T.W. Whitaker. 1951. Recently introduced varieties of head lettuce and methods used in their development. U.S. Dept. Agr. Circ. 881 .

Jones, B.L. and P.W. Leeper. 1971. Sources of immunity from races 5 and 6 of lettuce downy mildew (Bremia lactucae). Plant. Dis. Rptr. 55:794-796.

Ryder, E.J. 1987. Lettuce breeding, p. 436-476. In: M.J. Basset (ed.). Breeding vegetable crops. AVI, Westport, Conn.

Sleeth, B. and P.W. Leeper. 1966. Mildew resistant lettuce susceptible to a new physiologic race of Bremia lactucae in south Texas. Plant Dis. Rptr. 50:460.

Welch, J.E., R.G. Grogan, F.W. Zink, G.M. Kihara, and K.A. Kimble. 1965. 'Calmar'-A new lettuce variety resistant to downy mildew. Calif. Agr. 19:3. 